\title{
Studies on Genetic Variability, Heritability and Genetic Advance for Yield and Yield Components in Drought Tolerant Rice (Oryza sativa L.) Landraces
}

\author{
S.K. Singh, Monika Singh, Prudhvi Raj Vennela*, D.K. Singh, \\ Shubhra N. Kujur and Dinesh Kumar
}

Department of Genetics and Plant Breeding, IASc, BHU, Varanasi (UP), India

*Corresponding author

K e y w o r d s
$\begin{aligned} & \text { Drought, Genetic } \\ & \text { advance, GCV, } \\ & \text { Heritability, PCV } \\ & \text { and Variability }\end{aligned}$
Article Info
Accepted:
04 February 2018
Available Online:
10 March 2018

\section{Introduction}

Rice is a cereal crop, belongs to genus Oryza of Poaceae family. It is cultivated in 114 countries across the globe, but 90 percent of world's rice is grown in Asia (FAO, 2016). It is the staple food across Asia where around

\section{A B S T R A C T}

Information regarding genetic variation for drought attributes, their heritability and genetic advance coupled with association of different component traits among themselves and with grain yield are of immense help to breeder for selection of parents in hybridization programme. Phenotypic variation does not directly indicate its usefulness for selection in order to obtain genetic improvement unless the genetic fraction of variation is known. Therefore, it is important to partition out the genotypic component of total variation to arrive at reliable conclusion about the exploitable (genetic) variability in a set of genotypes. The present investigation was carried out at the Agriculture Research Farm, Institute of Agricultural Sciences, BHU, Varanasi during the kharif-2016 using 20 diverse rice genotypes with the objectives to assess direct selection parameters (variability, heritability and genetic advance). The results of the investigation revealed the high estimates of genotypic coefficient of variation and phenotypic coefficient of variation were observed for traits viz. sterile spikelets per panicle followed by grains yield per plot and grain yield per plant. Low magnitude of GCV and PCV was exhibited by canopy temperature depression followed by chlorophyll content and amylose content, rest other traits exhibited medium values of PCV. Further, high heritability coupled with high expected genetic advance as percent of mean was also observed for the traits viz. panicle weight, grain yield per plant, kernel breadth, kernel L/B ratio, proline content $(99 \%)$ followed by days to $50 \%$ flowering, days to first flowering, panicle length $(98 \%)$ and 1000 grain weight, kernel length $(97 \%)$. Lowest heritability was observed in canopy temperature depression (24\%) followed by chlorophyll content (36\%) and stomatal conductance $(53 \%)$. Other traits showed intermediate heritability. 
than previous year's projection. Similarly, the Indian rice production is expected to be around $109 \mathrm{mt}$ during the year 2016-17 which is the highest ever production of rice till date (AICRIP annual meeting report 2017). About $25 \%$ of the world's rice area is under rainfed lowlands. Water is the critical and most important factor in rice production. Drought reduces yield by $15-50$ per cent depending on the stress intensity and crop growth period at which the stress occurs in rice (Srividhya et al., 2011). Genetic variability for agronomic traits is the key component of breeding programs for broadening the gene pool of rice and would require reliable estimates of heritability in order to plan an efficient breeding program. Yield component breeding to increase grain yield would be most effective, if the components involved are highly heritable and genetically independent or positively correlated with grain yield. However, it is very difficult to judge whether observed variability is highly heritable or not. Moreover, knowledge of heritability is essential for selection based improvement as it indicates the extent of transmissibility of a character into future generations (Sabesan et al., 2009). So by considering the above points the present investigation was conducted with an objective to assess direct selection parameters (variability, heritability and genetic advance).

\section{Materials and Methods}

The field experiment was conducted at the Agricultural Research Farm, Institute of Agricultural Sciences, Banaras Hindu University, Varanasi. The present research work confined with 20 rice landraces (drought donors including checks) which were received from the project of Stress Tolerant Rice for Africa and South Asia (STRASA), IRRI, Philippines (Table 1). The experiment was laid out in randomized block design (RBD) with three replications. The nursery was raised on uniform raised beds applied with recommended fertilizer dose. Twenty one days old seedlings were transplanted in main research plot with one seedling per hill. The recommended agronomic practices were followed to raise a good and healthy crop. A bund was made all around the field and water was removed from the field regularly to create drought environment. Data was recorded on five competitive normal looking plants from each treatment in each replication randomly to record the following observations for twenty seven quantitative Viz., Days to 50 per cent flowering, Days to maturity, Plant height (cm), Number of tillers per plant, Number of effective tillers per plant, Panicle length $(\mathrm{cm})$, Number of Spikelets per panicle, Number of grains per panicle, Number of Sterile spikelets per panicle, Grain weight per panicle (g), 1000- grain weight (g), Grain yield per plant (g), Grain yield per plot (g), Biomass (kg/ha), Harvest Index, Grain quality characters, Hulling recovery, Milling recovery, Kernel length $(\mathrm{mm})$, Kernel breadth $(\mathrm{mm})$, Kernel L/B ratio, Amylose content, Canopy temperature depression (CTD), Stomatal conductance $\quad\left(\mathrm{mmol} / \mathrm{m}^{2} / \mathrm{s}\right)$, Chlorophyll content (SPAD value), Proline content ( $\mu \mathrm{mol} / \mathrm{g}$ fresh weight). Phenotypic and genotypic coefficient of variation was calculated by the method suggested by Burton and Devane (1953). Heritability was calculated by the formula given by Allard (1960) and genetic advance i.e. expected genetic gain resulting from selecting five per cent superior plants was estimated by the following formula suggested by Allard (1960). The data was analyzed by windostat version 9.2 with indostat services.

\section{Results and Discussion}

The experimental results obtained from the present study are as follows. The analysis of 27 traits was carried out to partition the total variation into genotypic variation and 
variation due to other sources. Analysis of variance was based on the mean values of eleven quantitative traits in 20 rice genotypes. The results pertaining to phenotypic coefficient of variation (PCV), genotypic coefficient of variation (GCV), heritability (broad sense) and genetic advance expressed as percent of mean for all the characters under study are presented in Table 2.

The results of ANOVA revealed considerable variation over the traits under study exhibiting a wide range of phenotypic as well as genotypic coefficient of variation. In general, the values of phenotypic coefficient of variance were higher than those of genotypic coefficient of variance. The relative magnitudes of the phenotypic as well as genotypic variances between the traits were compared based on the phenotypic and genotypic coefficient of variation. PCV was recorded highest for sterile spikelets per panicle (67.48) followed by grains yield per plot (43.24) and grain yield per plant (38.31). Low magnitude of PCV was exhibited by canopy temperature depression (1.98) followed by chlorophyll content (5.32) and amylose content (5.37). The remaining traits exhibited medium values of PCV.

Similarly, GCV was also high for sterile spikelets per panicle (65.94) followed by grains yield per plot (42.22) and grain yield per plant (38.21). Whereas, low magnitude of GCV was exhibited by canopy temperature depression (0.96) followed by chlorophyll content (3.2) and days to maturity (7.03). The differences between the values of PCV and GCV were small for almost all the traits indicating less influence of environment in expression of these traits. However, the differences was comparatively greater in case of stomatal conductance (5.29) followed by effective tillers per plant (4.42) and tillers per plant (2.44).
In the present study, heritability (broad sense) ranged from $36 \%$ to $99 \%$. The highest heritability was found in days to maturity, plant height, grain weight per panicle, grain yield per panicle, grain yield per plant, kernel breadth, kernel L/B ratio, proline content $(99 \%)$ followed by days to $50 \%$ flowering, days to first flowering, panicle length (98\%) and 1000grain weight, kernel length (97\%). Lowest heritability was observed in canopy temperature depression (24\%) followed by chlorophyll content $(36 \%)$ and stomatal conductance $(53 \%)$. Other traits showed intermediate heritability.

Genetic advance as percent of mean (5\%) was realized highest for sterile spikelets per panicle (132.75) followed by grain yield per plot (84.92) and grain yield per plant (78.49). Lowest value was observed in canopy temperature depression (0.97) followed by chlorophyll content (3.97) and amylose content (10.11).

The magnitude of genetic variability decides the effectiveness of selection. It is an established fact that greater the variability among the genotypes better is the chance for further improvement in the crop. But this variability can be utilized better if it is heritable. The heritable portion of the overall observed variation can be ascertained by studying the components of variation such as GCV, PCV, heritability and predicted genetic advance. In this study, the estimates of PCV were higher than their corresponding GCV for all the traits studied. These findings were similar to the findings of Souroush et al., (2004) and Singh et al., (2013). The highest PCV and GCV were high recorded for sterile spikelets per panicle followed by grains yield per plot and grains yield per plant indicating that these traits were under the major influence of genetic control and less variable due to environmental factors. Therefore, such traits are important for further improvement. 
Table.1 List of 20 landraces and their sources

\begin{tabular}{|c|c|c|}
\hline S. No. & Name of Genotype & Source \\
\hline 1 & B 6149 F-MR-7 & I.R.R.I., Philippines (S.A. Hub) \\
\hline 2 & DZ 78 & I.R.R.I., Philippines (S.A. Hub) \\
\hline 3 & E KHAKEHA & I.R.R.I., Philippines (S.A. Hub) \\
\hline 4 & E ZI 124 & I.R.R.I., Philippines (S.A. Hub) \\
\hline 5 & GOPAL & I.R.R.I., Philippines (S.A. Hub) \\
\hline 6 & KAUKHMWE & I.R.R.I., Philippines (S.A. Hub) \\
\hline 7 & NP 125 & I.R.R.I., Philippines (S.A. Hub) \\
\hline 8 & NS 252 & I.R.R.I., Philippines (S.A. Hub) \\
\hline 9 & RTS 4 & I.R.R.I., Philippines (S.A. Hub) \\
\hline 10 & SOLOI & I.R.R.I., Philippines (S.A. Hub) \\
\hline 11 & TCHAMPA & I.R.R.I., Philippines (S.A. Hub) \\
\hline 12 & VELLAISEENETTI & I.R.R.I., Philippines (S.A. Hub) \\
\hline 13 & WANNIDAHANALA & I.R.R.I., Philippines (S.A. Hub) \\
\hline 14 & WAR 72-2-1-1 & I.R.R.I., Philippines (S.A. Hub) \\
\hline 15 & XINUOZAO & I.R.R.I., Philippines (S.A. Hub) \\
\hline 16 & IR -74371-54-1-1 & I.R.R.I., Philippines (S.A. Hub) \\
\hline 17 & IR -119 & I.R.R.I., Philippines (S.A. Hub) \\
\hline 18 & IR-64 & I.R.R.I., Philippines (S.A. Hub) \\
\hline 19 & SWARNA & ANGRAU, Hayderabad \\
\hline & Local checl & NDUAT Faizabad \\
\hline
\end{tabular}

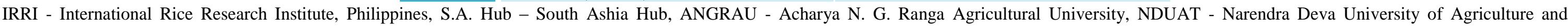
Technology

Table.2 ANOVA of 20 rice genotypes for twenty seven yield and yield attributing trait

\begin{tabular}{|c|c|c|c|c|c|c|c|c|c|c|c|c|c|c|c|c|c|c|c|c|c|c|c|c|c|c|c|}
\hline & $\begin{array}{r}\text { Days to } \\
\text { First } \\
\text { Flowering }\end{array}$ & $\begin{array}{r}\text { Days to to } \\
50 \% \\
\text { Flowering }\end{array}$ & $\begin{array}{c}\text { Days to } \\
\text { Maturity }\end{array}$ & $\begin{array}{c}\text { Plant } \\
\text { Height } \\
\mathrm{cm}\end{array}$ & $\begin{array}{c}\begin{array}{c}\text { Ttillers/ } \\
\text { Plant }\end{array} \\
\text { Pats }\end{array}$ & 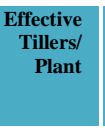 & $\begin{array}{r}\text { Panicle } \\
\text { Length } \\
(\mathrm{cm})\end{array}$ & $\begin{array}{c}\begin{array}{c}\text { Spikelets/ } \\
\text { Panicle }\end{array} \\
\text { a }\end{array}$ & $\begin{array}{l}\text { Grains/ } \\
\text { Panicle }\end{array}$ & $\begin{array}{c}\text { Sterile } \\
\text { Spiteletstl } \\
\text { Panicle }\end{array}$ & $\begin{array}{l}\text { Spikelet } \\
\text { Fertility } \\
\% \%\end{array}$ & $\begin{array}{r}\text { Grain } \\
\text { Weight/ } \\
\text { Paninlel } \\
\text { (g) }\end{array}$ & $\begin{array}{r}1000- \\
\text { Grain } \\
\text { Weight } \\
\text { (g) }\end{array}$ & $\begin{array}{r}\text { Grain } \\
\text { Yielal } \\
\text { Plant } \\
\text { (g) }\end{array}$ & $\begin{array}{r}\text { Hulling } \\
\text { Recovery } \\
\%\end{array}$ & $\begin{array}{l}\text { Milling } \\
\text { Recovery\% }\end{array}$ & $\begin{array}{l}\text { Kernel } \\
\text { Lengnth } \\
(\mathrm{mm})\end{array}$ & $\begin{array}{r}\text { Kernel } \\
\text { Breandth } \\
(\mathrm{mm})\end{array}$ & 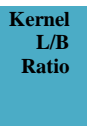 & $\begin{array}{l}\text { Amylose } \\
\text { Content }\end{array}$ & $\begin{array}{c}\text { Canopy } \\
\text { Temperature } \\
\text { Depression }\end{array}$ & $\begin{array}{r}\text { Stomatal } \\
\text { Conductance } \\
\left(\mathbf{m m o l}^{2} / \mathbf{M}^{2} / \mathrm{S}\right)\end{array}$ & $\begin{array}{c}\text { Chlorophyll } \\
\text { Content } \\
\text { (spad } \\
\text { Value) }\end{array}$ & $\begin{array}{l}\text { Proline } \\
\text { Content } \\
\text { (umolg } \\
\text { Fresh } \\
\text { Weight) }\end{array}$ & $\begin{array}{c}\text { Grain } \\
\text { Yield/ } \\
\text { Plot }(\mathrm{kgg}\end{array}$ & $\begin{array}{c}\text { Biomass } \\
\text { (kg/ha) }\end{array}$ & $\begin{array}{c}\text { Harvest } \\
\text { Index }\end{array}$ \\
\hline GCV & 9.08 & 8.46 & 7.03 & 18.11 & 26.60 & 25.67 & 7.86 & 15.03 & 16.26 & 65.94 & 10.79 & 21.26 & 10.91 & 38.21 & 9.25 & 12.55 & 9.41 & 12.75 & 19.88 & 5.13 & 0.96 & 14.03 & 3.20 & 22.92 & 42.22 & 13.49 & 4.32 \\
\hline PCV & 9.19 & 8.53 & 7.08 & 18.23 & 29.03 & 30.09 & 7.95 & 15.42 & 16.56 & 67.48 & 11.01 & 21.38 & 11.06 & 38.31 & 9.51 & 13.04 & 9.55 & 12.81 & 20.00 & 5.37 & 1.98 & 19.33 & 5.32 & 23.02 & 43.24 & 14.52 & 34.95 \\
\hline $\mathbf{h}^{2}$ (Broad Sense) & 0.98 & 0.98 & 0.99 & 0.99 & 0.84 & 0.73 & 0.98 & 0.95 & 0.96 & 0.96 & 0.96 & 0.99 & 0.97 & 0.99 & 0.95 & 0.93 & 0.97 & 0.99 & 0.99 & 0.91 & 0.24 & 0.53 & 0.36 & 0.99 & 0.95 & 0.86 & 0.96 \\
\hline Gen.Adv as \% of Mean $5 \%$ & 18.48 & 17.28 & 14.39 & 37.05 & 50.19 & 45.12 & 16.02 & 30.16 & 32.90 & 132.75 & 21.80 & 43.56 & 22.16 & 78.49 & 18.53 & 24.88 & 19.08 & 26.15 & 40.69 & 10.11 & 0.97 & 20.99 & 3.97 & 47.01 & 84.92 & 25.81 & 69.42 \\
\hline General Mean & 89.63 & 94.55 & 117.37 & 157.19 & 6.35 & 4.95 & 27.01 & 141.53 & 116.95 & 24.55 & 84.80 & 2.70 & 23.63 & 9.39 & 81.49 & 71.51 & 6.37 & 2.31 & 2.86 & 23.95 & 29.27 & 751.41 & 42.71 & 17.34 & 0.46 & 1.56 & 28.53 \\
\hline Exp Mean next Generation & 106.20 & 110.89 & 134.26 & 215.43 & 9.54 & 7.18 & 31.34 & 184.22 & 155.42 & 57.14 & 103.28 & 3.88 & 28.87 & 16.76 & 96.59 & 89.30 & 7.59 & 2.91 & 4.02 & 26.37 & 29.55 & 909.14 & 44.41 & 25.49 & 0.84 & 1.97 & 88.33 \\
\hline Range Lowest & 79.33 & 84.00 & 106.67 & 93.13 & 4.33 & 3.33 & 23.30 & 105.67 & 84.33 & 11.33 & 52.93 & 1.74 & 18.04 & 4.57 & 62.20 & 50.89 & 5.29 & 1.89 & 2.04 & 21.16 & 28.70 & 527.17 & 38.60 & 9.06 & 0.21 & 1.15 & 16.77 \\
\hline Range Highest & 108.33 & 112.33 & 141.33 & 206.31 & 11.67 & 8.33 & 30.07 & 186.00 & 158.33 & 84.67 & 93.38 & 3.69 & 30.26 & 16.17 & 92.51 & 89.01 & 7.89 & 2.84 & 4.15 & 24.88 & 30.24 & 988.40 & 46.77 & 25.61 & 0.82 & 1.90 & \\
\hline
\end{tabular}


These findings are in close agreement with the researchers Anjaneyulu et al., (2010) and Singh et al., (2013). In the present study traits such as canopy temperature depression followed by chlorophyll content, days of maturity had low estimates of PCV and GCV indicating that selection for these traits will be less effective in comparison to remaining traits. The GCV provides a measure of comparison of variability and sometimes give some indication regarding validity of traits for selection. However, it does not provide clean picture of the extent of genetic gain to be expected from selection of phenotypic traits, unless heritable fraction of variation (heritability) is known (Burton, 1952). The difference between the values of PCV and GCV were small for almost all the traits indicating less influence of environment in expression of these traits suggesting phenotypic differences may be considered as genetic difference among genotypes for selection. However, the difference was comparatively greater in case of stomatal conductance followed by effective tillers and tiller per plant. This cautions that per-se performance of these traits should not be taken directly as the basis of selection other variability parameter for these traits such as heritability may also be taken into consideration.

The relative magnitude of genotypic and phenotypic variances for the traits is the broad sense heritability and it is used as analytical role in selection procedures. In the present investigation, high heritability was recorded for most of the characters except spikelet fertility per cent and number of effective tillers. Days to $50 \%$ flowering and days to maturity exhibited highest heritability followed by panicle length and total grains per panicle. Similar results were obtained by Mahto et al., (2003), Aktar et al., (2004), Singh et al., (2007), Chouhan et al., (2014) and Lingaiah (2015) in rice genotype they studied. This indicated that selection of these traits would be more effective as compared to others.

High heritability does not always indicate high genetic gain. Heritability and genetic advance are important selection parameters. Heritability estimates along with genetic advance are normally more helpful in predicting the gain under selection than heritability estimates alone. It is not necessary that a character showing high heritability will also exhibit high genetic advance. The breeder should be cautious in making selection based on heritability as it indicates both additive and non-additive gene action. Thus, heritability values coupled with genetic advance would be more reliable and useful in formulating selection procedure as it indicates that most likely the heritability is due to additive gene effects. In the present set of materials, high heritability coupled with high genetic advance as percent was recorded for panicle weight, total grains per panicle and filled grains per panicle indicating effectiveness of selection for the improvement of these traits while high heritability coupled with low genetic advance as percent of mean were observed for panicle length, days to maturity and days to $50 \%$ flowering which is indicative of non-additive gene action. High heritability coupled with high genetic advance may be attributed to additive gene action. The high heritability is being exhibited due to favorable influence of environment rather than genotype and selection for such traits may not be rewarding. These results are in conformity with the findings of Krishna et al., (2010), Singh et al., (2012) and Sawarkar and Senapati (2014).

In conclusion the Analysis of variance revealed the highly significant differences among the genotypes for all the characters under study. The genotypes exhibited a wide range of variability for most of the traits. This 
indicated that there is ample scope for selection of promising genotypes from present set of genotypes for yield improvement. On the basis of per se performance, genotypes viz., RTS4, SWARNA, NS252, IR-74371-541-1 and IR 119 were found to be the best for yield and yield contributing traits. Therefore, these can be successfully utilized as parents in future breeding programme. Genotype MGD 1206 was earliest in flowering and maturity suggesting that this genotype can be used as a donor in hybridization programme for evolving early maturing rice variety.

The high estimates of genotypic coefficient of variation and phenotypic coefficient of variation were observed for traits viz. sterile spikelets per panicle followed by grains yield per plot and grain yield per plant. Low magnitude of GCV and PCV was exhibited by canopy temperature depression followed by chlorophyll content and amylose content, rest other traits exhibited medium values of PCV. Further, high heritability coupled with high expected genetic advance as percent of mean was also observed for the traits viz. panicle weight, grain yield per plant, kernel breadth, kernel L/B ratio, proline content $(99 \%)$ followed by days to $50 \%$ flowering, days to first flowering, panicle length (98\%) and 1000grain weight, kernel length (97\%). Lowest heritability was observed in canopy temperature depression (24\%) followed by chlorophyll content (36\%) and stomatal conductance $(53 \%)$. Other traits showed intermediate heritability.

Atlast, the present study has revealed valuable information on different yield traits in rice improvement. Genotypes SWARNA, RTS4 E KHA KEHA, IR 119 and IR 64 were found to be the promising genotypes for yield and yield contributing traits. Hence these genotypes can be utilized in future breeding programme to obtain potential transgressive segregants.

\section{Acknowledgements}

The authors also thankful to Dr. Arvind Kumar, who provided seed material under "Stress Tolerant Rice for Africa and South Asia" (STRASA) funded by IRRI Philippines.

\section{References}

Akter, K., Iftekharuddaula, K. M., Bashar, M. K., Kabir, M. H. and Sarkar, M. Z. A. (2004). Genetic variability, correlation and path analysis in irrigated hybrid rice. Journal of Subtropical Agricultural Research and Development 2(1): 17-23.

Anjaneyulu, M., Reddy, D. R. and Reddy, K. H. P. (2010). Genetic variability, heritability and genetic advance in rice (Oryza sativa L.). Research on Crops. 11(2): 415-416.

Burton, G. W.and Devane, E. H. (1953). Estimating heritability in tall fescue (Festuca arundinacea) from replicated clonal material. Agronomy Journal, 45(10), 478-481.

Chouhan, S. K., Singh, A. K., Aparajita, S., Ram, M., Singh, P. K. and Singh, N. K. (2014). Characterization and evaluation of Oryza nivara and Oryza rufipogon. The Bioscan, 9(2): 853-858.

FAO, 2016.

http://ricepedia.org/rice-as-a-crop.

Krishna, T., Kavita, A. and Pushpalata, T. (2010). Genetic variability, heritability and genetic advance for quantitative traits in rice (Oryza sativa L.) accession. Agricultural and Biological Research, 26(1): 13-19.

Lingaiah, N. (2015). Genetic variability, heritability and genetic advance in rice (Oryza sativa L.). Asian Journal of Environmental Science, 10(1): 110-112.

Mahto, R.N., Yadav, M.S. and Mohan, K.S. (2003).Genetic variation, character association and path analysis in rainfed 
upland rice. Indian Journal of Dryland Agriculture Research and Development, 18(2): 196-198.

Sabesan, T., Saravanan, K. and Anandan, A. (2009). Genetic divergence analysis for certain yield and quality traits in rice (Oryza sativa L.) grown in irrigated saline low land of Annamalainagar, South India. Journal of Central European Agriculture, 10(4): 405-410.

Sawarkar, A. and Senapati, B.K. (2014). Polygenic variations and cause effect relationship in some photo-insensitive recombinant inbred lines (RILs) of Basmati derivative. African Journal of Biotechnology, 13(1): 112-118.

Singh, M., Kumar, K. and Singh, R. P. (2007). Study of co-efficient of variation, heritability and genetic advance in hybrid rice. Oryza, 44(2): $160-162$
Singh, S.K., Vikash Sahu, Amita Sharma and Pradeep Kumar Bhati, (2013). Heterosis for yield and yield components in rice (Oryza sativa L.). Bioinfolet, 10(2): 752-761.

Souroush, H. R., Mesbah, M., Hossainzadeh, A. and Bozorgipour, R. (2004). Genetic and phenotypic variability and cluster analysis for quantitative and qualitative traits of rice. Seed and Plant, 20(2): $167-182$.

Srividhya, A., Vemireddy, L. R., Sridhar, S., Jayaprada, M., Ramanarao, P. V., Hariprasad, A. S. and Siddiq, E. (2011). Molecular mapping of QTLs for yield and its components under two water supply conditions in rice (Oryza sativa L.). Journal of Crop Science and Biotechnology, 14(1): 45-56.

\section{How to cite this article:}

Singh S. K., Monika Singh, Prudhvi Raj Vennela, D. K. Singh, Shubhra N. Kujur and Dinesh Kumar. 2018. Studies on Genetic Variability, Heritability and Genetic Advance for Yield and Yield Components in Drought Tolerant Rice (Oryza sativa L.) Landraces. Int.J.Curr.Microbiol.App.Sci. 7(03): 299-305. doi: https://doi.org/10.20546/ijcmas.2018.703.035 